\title{
THREE PHASE ACTIVE POWER FILTER BASED ON NEURAL NETWORK OF CURRENT CONTROLLED VOLTAGE SOURCE INVERTER
}

\author{
E. E. EL-Kholy, A. EL-Sabbe, \\ and A. El-Hefnawy \\ Electrical Engineering Departement, \\ Faculty of Engineering, Menoufiya \\ University Shebin El-Kom, Egypt.
}

\author{
Hamdy M. Mharous \\ International Steel \\ Rolling Mill (ISRM), \\ Sadat, Egypt.
}

\begin{abstract}
:
This paper presents a shunt active power filter to compensate reactive power and reduce the unwanted harmonics in the supply current. A shunt active filter is realized employing three-phase IGBT bridge based voltage source inverter (VSI) with common DC bus capacitor. Two different proposed control methods for determining the reference compensating currents of the three-phase shunt active power filters based on proportional- integral (PI) controller and Artificial Neural Nettiork (ANN) are presented. Current controller based on hysteresis current controller is used to generate the firing pulses of VSI inverter. The shunt active filter acts as a current source, which is connected in parallel with a nonlinear load and controlled to generate the required compensation currents. The proposed system is implemented using a high speed Digital Signal Processor (DSP). Experimental and simulation results with different nonlinear loads are presented to conform the validity of the proposed control strategies.
\end{abstract}

\section{1- INTRODUCTION:}

In modern electric power distribution system, the wide applications of power electronics systems such as AC-DC adjustable speed drives, arc furnaces, traction, welding, computer power supplies, lighting, heating, air conditioning and asynchronous AC-DC-AC links...etc, are causes number of harmonics and poor power factor at the supply. The current drawn from these converters are nonsinusoidal and generate a serious number of disturbances in the supply net and deforms its output waveforms [1-2]. Using passive filters generally reduces the pervious disturbances but the solution with passive filters has many disadvantages [3-5], such as:

\footnotetext{
Manuscript received from Dr. E.E-El-Kholy

Accepted on : 19/9/2002

Engineering Research Journal Vol 25, No 4, 2002 Minufiya University, Faculty Of

Engineering, Shebien El-Kom, Egypt , ISSN 1110-1180
} 
- They cannot compensate for frequency variations;

-Their operation depends on the electricity supply network impedance and the characteristics of the nonlinear loads;

-When the harmonic current components increase, the filter may be over loaded; -Their dimensions and weights are large;

-Parallel resonance between the power system and the passive filter causes amplification of harmonic currents on the source side at a special frequency;

-Fixed capacitance, however, would cause an improvement of the power factor within a narrow range of the firing angle variation of the converters;

-The components of passive filters have aging and tuning problems;

The presented work describe the shunt active filters to overcome the disadvantages of the passive filters. The shunt active power filters (SAF) have been investigated and developed [6-8], and have gradually been recognized as a feasible. solution to the problems created by nonlinear loads. They are used to eliminate the unwanted harmonics of the supply current and compensate fundamental reactive power consumed by nonlinear loads by injecting the compensation currents into the AC lines. Besides eliminating harmonic currents and improving the power factor, shunt active power filter has the capability to compensate randomly varying currents.

This paper proposes a shunt active filter (SAF) with two different approaches to calculate the reference currents of the SAF: The first method is used P-I controller depend on the dc bus voltage of the inverter. The second method based on Neural Network to extract the distorted load current from sinusoidal reference supply current.. A hysteresis current controller based PWM current control is used to generate the required pulses for the voltage source inverter according to the compensating currents of the SAF and its derived reference currents.

\section{2- SYSTEM DESCRIPTION AND OPERATION:}

Figure 1 shows the diagram of the proposed system. This system consists of VSI contains a three-phase IGBT bridge anti-paralleling with diodes. The VSI is connected in Parallel with the three-phase supply through three inductors $L_{\mathrm{fl}}, \mathrm{L}_{\mathrm{f} 2}$ and $\mathrm{L}_{13}$. The DC side of the VSI is connected to a DC capacitor, $\mathrm{C}$, that the main reactive energy storage element. The inductors $L_{f 1}, L_{f 2}$ and $L_{f 3}$ perform the voltage boost operation in combination with the capacitor, and at the same time act as the low pass filter for the AC source current. Then the SAF must be controlled to produce the compensating currents $i_{f 1}, i_{f 2}$ and $i_{f 3}$ which are follow the reference compensating currents $\mathrm{i}_{\mathrm{f1}} * \mathrm{i}_{\mathrm{f}}{ }^{*}$ and $\mathrm{i}_{\mathrm{f}}{ }^{*}$.

\section{2-1 System Modeling:}

The representation of three-phase voltages and currents of the VSI shown in Fig. (1) are as follows: the voltages $V_{f l}, V_{f 2}$ and $V_{f 3}$ are the output of the inverter can be expressed as a function of the capacitor voltage $V_{c}$ and the switching 


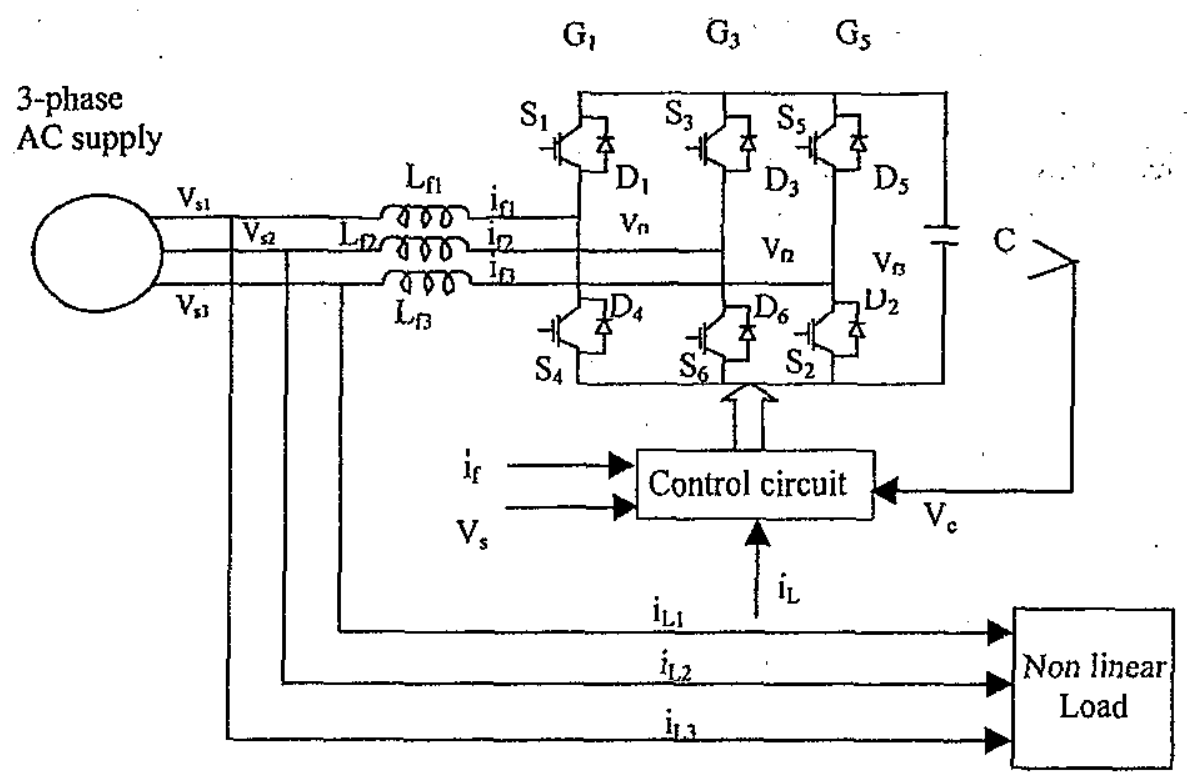

Fig. (1) The proposed shunt active power filter

functions $\mathrm{G}_{1}, \mathrm{G}_{3}$ and $\mathrm{G}_{5}$ of the VSI as follows :

$$
\left[\begin{array}{c}
V_{f 1} \\
V_{f 2} \\
V_{f 3}
\end{array}\right]=\frac{V_{c}}{6}\left[\begin{array}{ccc}
-2 & 1 & 1 \\
1 & -2 & 1 \\
1 & 1 & -2
\end{array}\right]\left[\begin{array}{l}
G_{1} \\
G_{3} \\
G_{5}
\end{array}\right]
$$

Where $G_{1}, G_{3}$ and $G_{5}$ represent three switching functions $(1$ or -1$)$ of the three legs of the inverter. The inverter conduction state is represented by these logics, a logic ' 1 ' means that one upper element of the VSI is conducting and a logic '-1'means that one lower element is conducting. Then the SAF currents can be written as:

$L_{\mathrm{f} 1} \frac{\mathrm{di}_{\mathrm{f} 1}}{\mathrm{dt}}=\mathrm{V}_{\mathrm{s} 1}-\mathrm{V}_{\mathrm{f} 1}$

$\mathrm{L}_{\mathrm{f} 2} \frac{\mathrm{di}_{\mathrm{f} 2}}{\mathrm{dt}}=\mathrm{V}_{\mathrm{s} 2}-\mathrm{V}_{\mathrm{f} 2}$

$L_{\mathrm{B}} \frac{\mathrm{di}_{\mathrm{f3}}}{\mathrm{dt}}=\mathrm{V}_{\mathrm{s} 3}-\mathrm{V}_{\mathrm{f3}}$

Where $i_{f 1}, i_{f 2}$ and $i_{f 3}$ are $S A F$ currents and $V_{s 1}, V_{s 2}$ and $V_{s 3}$ are the supply voltages. The capacitor DC voltage can be calculated from the SAF currents and switching function as follows:

$\mathrm{V}_{\mathrm{c}}=-\frac{1}{C} \int\left[G_{1} \mathrm{i}_{\mathrm{f} 1}+G_{3} \mathrm{i}_{\mathrm{f} 2}+G_{5} \mathrm{i}_{\mathrm{f} 3}\right]$

The set point of the storing capacitor voltage must be greater than the peak value of the line to neutral supply voltage in order to be able to shape properly the mains currents.

\section{3- THE PROPOSED CONTROL METHODS:}

The quality and performance of the SAF depends mainly on the method implemented to generate the compensating reference currents. This paper explained two methods to get the reference SAF currents, 


\section{3-1- DC bus Voltage method:}

The basic operation of this proposed control method is shown in Fig.(2). The estimation of the reference currents from the measured DC bus voltage is the basic idea behind the PI controller based operation of the SAF. As shown in Fig. (2), the capacitor voltage is compared with its reference value $V_{c}{ }^{*}$ and the error is the input to the PI. The output of PI controller is multiplied by the supply voltage waveform $V_{s 1}, V_{s 2}, V_{s 3}$ in order to obtain the supply reference currents $i_{s 1}{ }^{*}, i_{s 2}{ }^{*}, i_{s}{ }^{*}$. So the supply reference currents are proportional to the supply voltages. The three-phase compensating reference current of $\operatorname{SAF}\left(\mathrm{i}_{\mathrm{f} 1}{ }^{*}, \mathrm{i}_{\mathrm{f} 2}{ }^{*}, \mathrm{i}_{\mathrm{f}}{ }^{*}\right)$ are estimated using reference supply currents and sensed actual load currents. Reference SAF currents are compared with its actual value and the error between them is the input to hystisese current controller. The hysterises controller output is used to generate the required pulses of VSI.

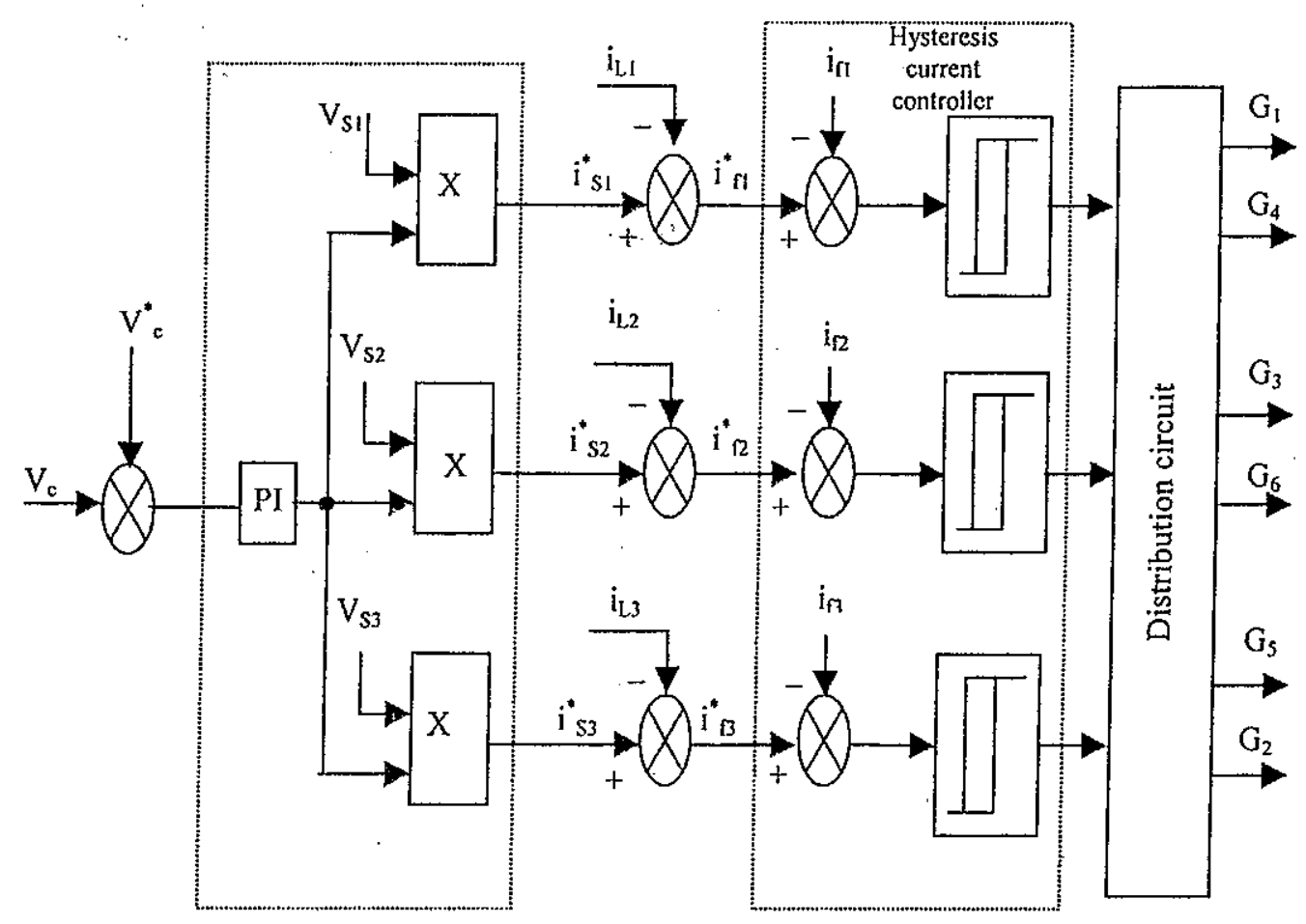

Fig. (2) The proposed control system

\section{3-2- Proposed control method with ANN:}

The proposed control method is based on the recovering of the fundamental active phase currents in the load. Once these currents are obtained, they are subtracted from the total load currents to get the desired reference SAF currents. Let to assume that the nonlinear load current of the plant can be represented as:

$$
\begin{aligned}
i_{L} & =i_{1} \cos \varphi \sin w t+i_{1} \sin \varphi \cos w t+\sum_{n=2}^{\infty} i_{n} \sin \left(n w t+\varphi_{n}\right) \\
& =\mathrm{i}_{\mathrm{p}}(\mathrm{t})+\mathrm{i}_{\mathrm{q}}(\mathrm{t})+\mathrm{i}_{\mathrm{h}}(\mathrm{t})
\end{aligned}
$$

Where $i_{p}(t)$ represents the active current, $i_{q}(t)$ represents the reactive current and $i_{h}(t)$ represents the sum of all harmonic currents. If the SAF can generate $i_{f}(t)$ which is equivalent to $i_{\mathfrak{q}}(t)+i_{h}(t)$, then the supply must be give the active current $i_{p}(t)$, which is sinusoidal and in phase with the supply voltage $V_{s}(t)$. Equation (6) becomes; 
$i_{f}(t)=i_{L}(t)-i_{p}(t)=i_{L}(t)-I_{1} \cos \varphi \sin \omega t$ $i_{f}(t)=i_{L}(t)-W V_{s}(t)$ where $\sin \omega \mathrm{t}=\mathrm{V}_{\mathrm{s}} / \mathrm{V}_{\mathrm{m}}$ where $\mathrm{W}=\mathrm{I}_{\mathrm{l}} \cos \varphi / \mathrm{V}_{\mathrm{m}}$
(7)

$(8)$

According to calculation of W, the reference current of the SAF is calculated. These currents are changed according to the nonlinear. load current and the supply voltage. The calculation of $\mathrm{W}$ is based on neural network. The basic principle diagram of this control algorithm is shown in Fig. (3).

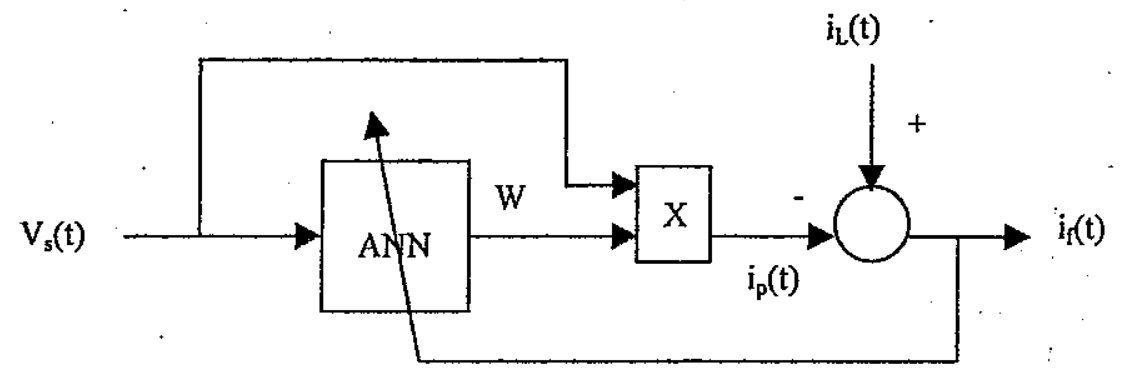

Fig.(3)The basic principle diagram of the proposed method

The ANN, consists of a neurons net that is an adaptive linear element, the weight of the neuron is equivalent $\mathrm{W}$ and the bias is equivalent to zero. The input is the supply voltage $V_{s}(t)$, the output is fundamental active current $i_{p}(t)$ and the output of the system is the SAF reference current $\mathrm{i}_{\mathrm{f}}{ }^{*}$. According to The WidrowHoff learning rule, the update weight equation as follows:

$$
\mathrm{W}(\mathrm{n})=\mathrm{W}(\mathrm{n}-1)+\eta \mathrm{i}_{\mathrm{f}}^{*} \mathrm{Vs}(\mathrm{n}-1)
$$

Where the term $\eta \mathrm{i}_{\mathrm{f}}^{*} V_{\mathrm{s}}(\mathrm{n}-1)$ is represents the change of weight.

$\mathrm{i}_{\mathrm{f}}^{*}(\mathrm{n})=\mathrm{i}_{\mathrm{L}}(\mathrm{n})-\mathrm{W}(\mathrm{n}) \mathrm{V}_{\mathrm{s}}(\mathrm{n})$

From equations (9) and (10), the proposed control method for phase-a is designed, as shown in Fig.(4).

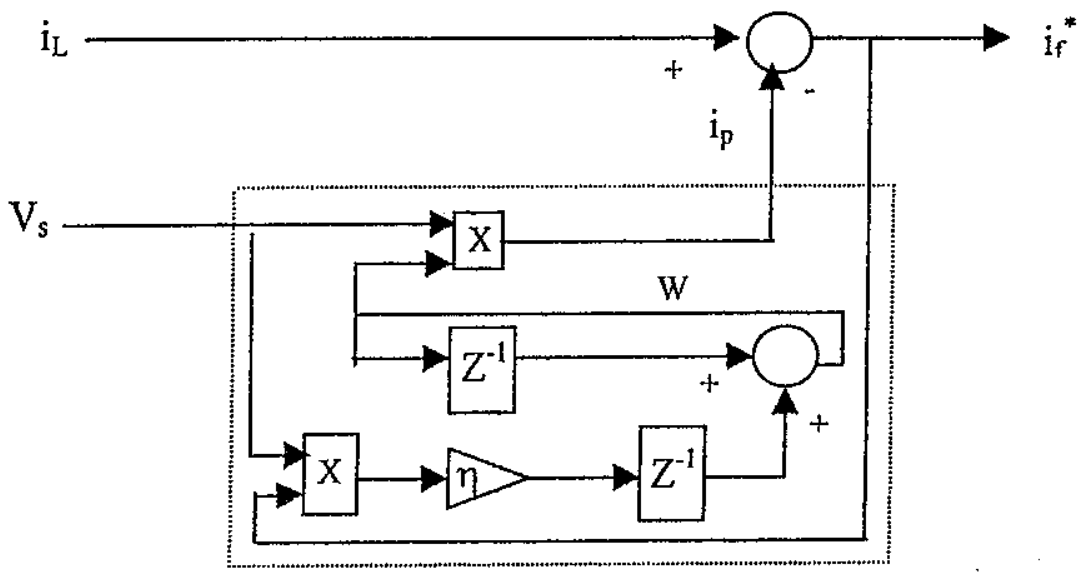

Fig. (4) The proposed control method for phase-a

The neural network learning and training by Widrow-Hoff learning rule (least mean square LMS algorithm) is used to obtain the weight (W). Then the SAF reference currents as calculated from the equation (10). After calculating the reference current for the SAF, by two methods, the dc-bus voltage PI controller and the neural network, the hysteresis current controller has been proposed to provide the pulses of the VSI that control SAF actual currents. 


\section{3-3- Hesteresis current controller:}

Hysteresis current controller with fixed band derives the switching signals of the inverter from the comparison of the current error to keep the current within the hysteresis band. Then the SAF reference currents $\mathrm{i}_{\mathrm{fl}} *, \mathrm{i}_{\mathrm{f}}{ }^{*}, \mathrm{i}_{\mathrm{f}}{ }^{*}$ compared with SAF feedback currents $i_{f 1}, i_{f 2}, i_{f 3}$ and the error signals are operated by the hysteresis current controller to generate the firing pulses which activate the inverter power switches in a manner that reduces the current error. Let $\left(h_{b}\right)$ is the width of the hysteresis band around the respective phase SAF currents, then the equation for the fixed band are as follows:

$\mathrm{i}_{\mathrm{fl}} *=\mathrm{i}_{\max } \sin \omega \mathrm{t}$

$\mathrm{i}_{\mathrm{up}}=\mathrm{i}_{\mathrm{ff}} *+\mathrm{h}_{\mathrm{b}}$

$i_{\text {low }}=i_{\mathrm{fl}} *-h_{\mathrm{h}}$

Where $i_{u p}$ is the upper band, $i_{\text {low }}$ is the lower band. If the SAF current feedback $i_{\mathrm{fl}}>$ $\left(i_{f 1}{ }^{*}+h_{b}\right)$ then $G_{1}=-1$, which means that the inverter output voltage switches to negative, in order to keep the current within the hysteresis band. If the SAF current feedback $i_{f l}<\left(i_{f 1} *-h_{b}\right)$ then $G_{1}=1$, which means that the inverter output voltage switches to positive, in order to increase the actual current. Similarly, the switching logic of other two-phase $G_{3}, G_{5}$ are derived

\section{4- Simulation results:}

A number of simulation results with different operating conditions 'were developed. The two control strategies considered are compared at the same condition of operation. In Fig. (5), SAF is connected in parallel with static nonlinear load (three-phase controlled rectifier with tesistance) through switch $\mathrm{sw}_{\mathrm{l}}$, in order to limit maximum slope of the rectifier current, a smoothing inductor $L_{r}$ has been inserted before the rectifier. This inductance is also prevented the inverter saturation even in correspondence of rectifier commutations. Since the compensation of the filter depends on the firing angle $(\alpha)$ of the rectifier. Two operative conditions have been considered. The controlled rectifier with the firing angle $\alpha=0^{\circ}$. is considered the first case, and the second is controlled rectifier with the firing angle $\alpha=40^{\circ}$. The parameters of this simulated system are reported as;

$\begin{array}{ll}\text { Input voltages } & \mathrm{V}_{\mathrm{s}}=380 \text { volt } \\ \text { Rectifier load resistance } & \mathrm{R}_{\mathrm{dc}}=100 \Omega \\ \text { Rectifier input inductor } & \mathrm{L}_{\mathrm{r}}=15 \mathrm{mH} \\ \text { Rectifier load current } & \mathrm{i}_{\mathrm{L}}=5 \mathrm{Amp} . \\ \text { SAF inductor } & \mathrm{L}_{\mathrm{f}}=30 \mathrm{mH} \\ \text { SAF DC link capacitor } & \mathrm{C}=250 \mu \mathrm{F} \\ \text { SAF DC link völtage } & \mathrm{V}_{\mathrm{c}}=750 \text { volt }\end{array}$

\section{4-1- Simulation of static load with controlled rectifier $\left(\alpha=0^{\circ}\right)$ :} 4-1-1- Steady state operation:

The simulation results in case of steady state operation when $\alpha=0^{\circ}$ are presented. Figure (6) shows the relevant system's waveforms with PI controller; the 


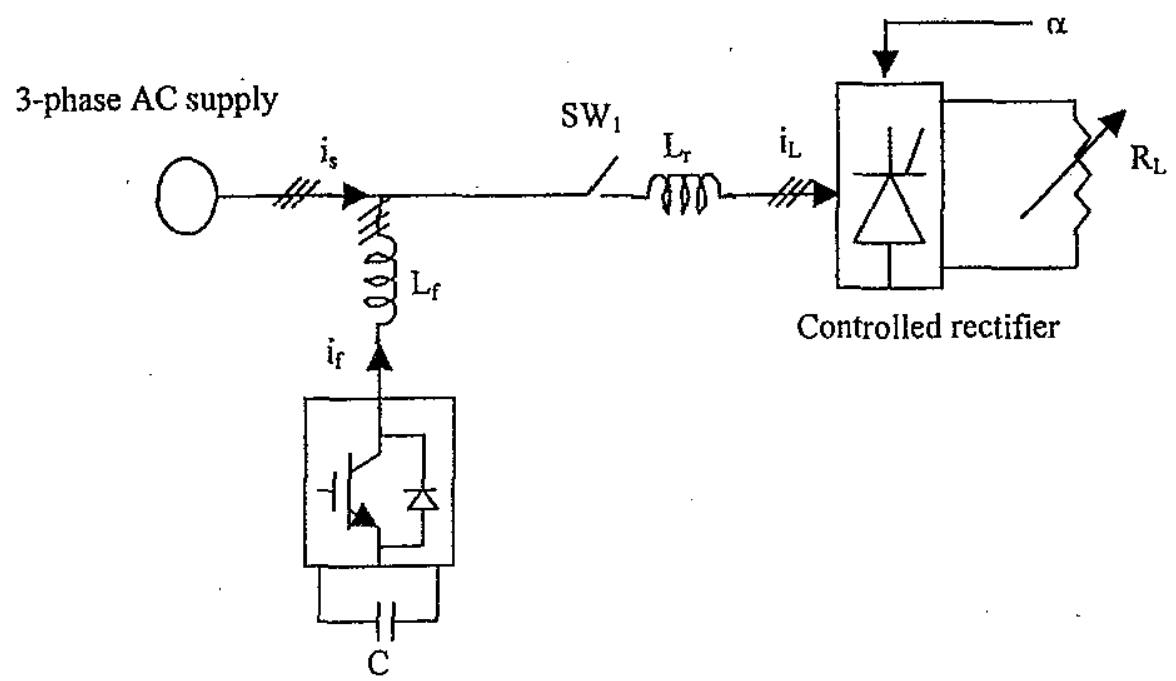

Fig. (5) SAF connected in parallel with different nonlinear loads.

source current without SAF fig.(6-a), the source current with SAF and the supply voltage fig.(6-b), the SAF current fig.(6-c), the capacitor voltage and its reference fig.(6-d). It is noticed that the supply current in phase with the supply voltage, and the capacitor voltage will follow its reference. In case of neural network control algorithm fig.(7) shows the source current with the supply voltage fig.(7-a), the SAF current fig.(7-b), and the weight of ANN fig.(7-c). This figure indicate that the supply current in phase with supply voltage. In order evaluate the performance of the control methods, total harmonic distortion (THD) are calculated for the source current before and after compensating. The calculation shows that THD improved from $24.04 \%$ without the SAF to $4.6156 \%$ in PI controller and $2.9156 \%$ in ANN control method with the SAF, as shown in fig. $(8-a, b, c)$. The distortion in supply current with ANN is less than in case of PI control method.

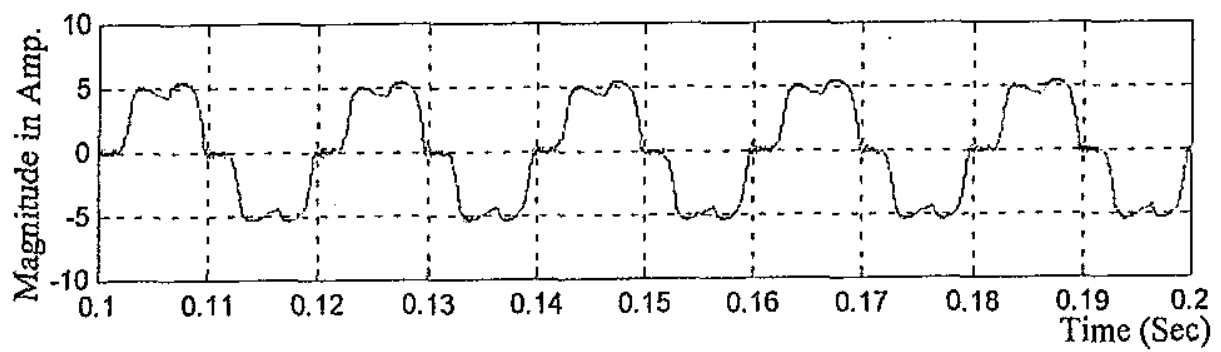

(6-a) Source current without filter

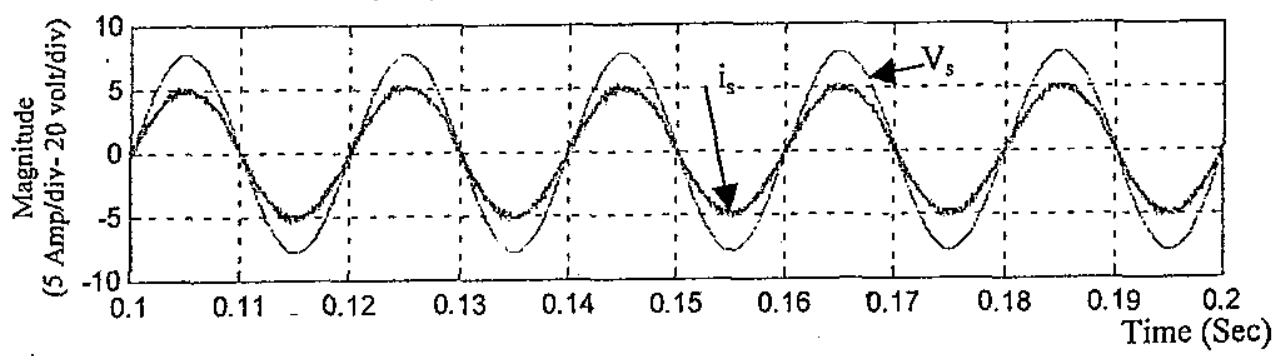

(6-b) Source current and source voltage with filter 


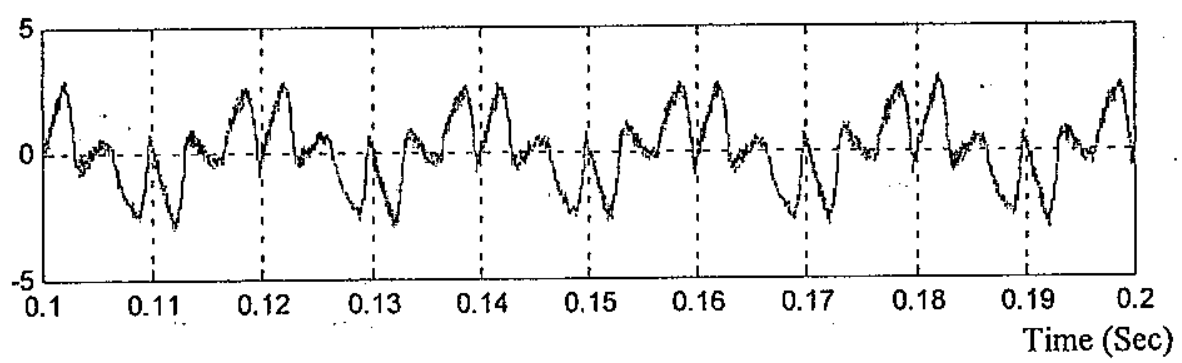

(6- c) compensating current

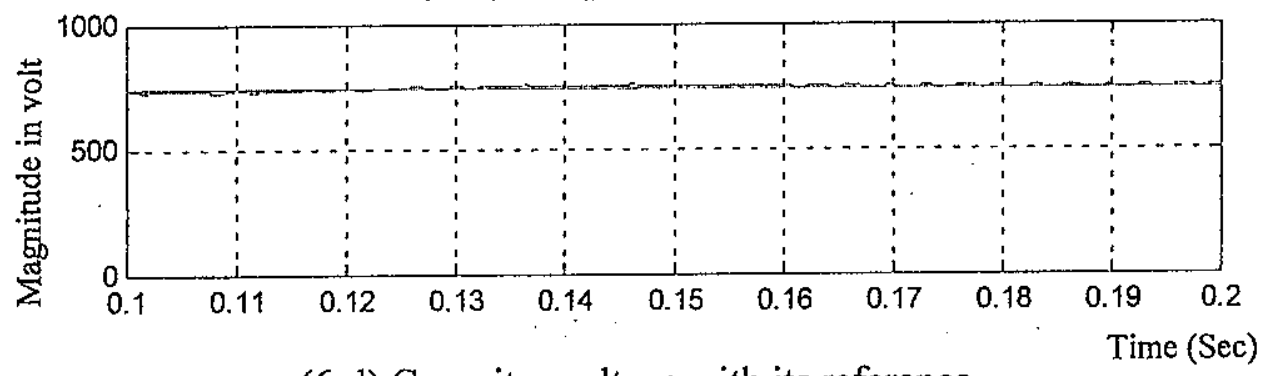

(6-d) Capacitor voltage with its reference

Fig.(6) Simulation results of proposed SAF using PI controller

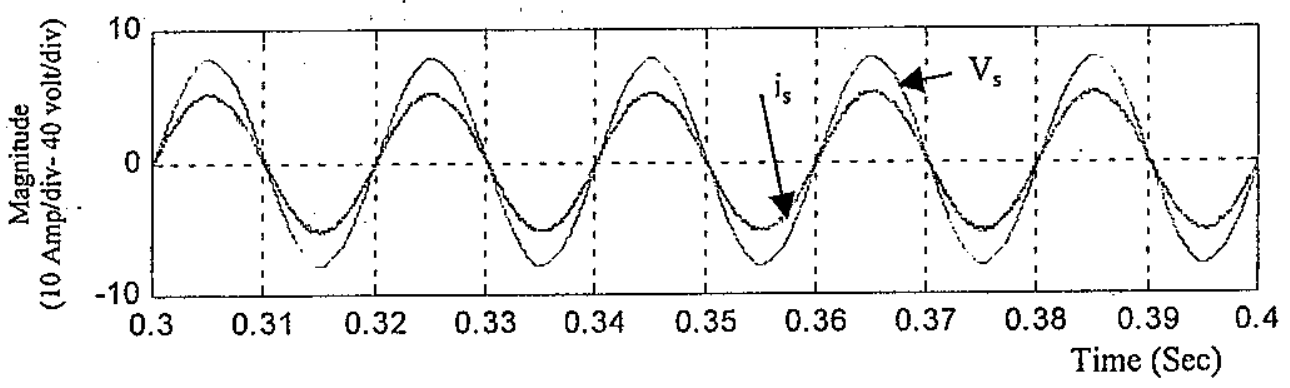

(7-a) Source current with SAF

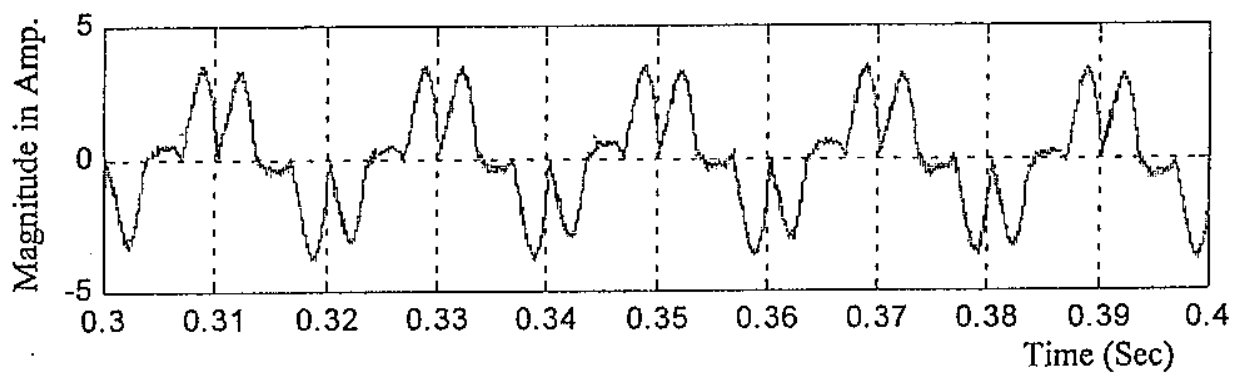

(7-b) Compensation current

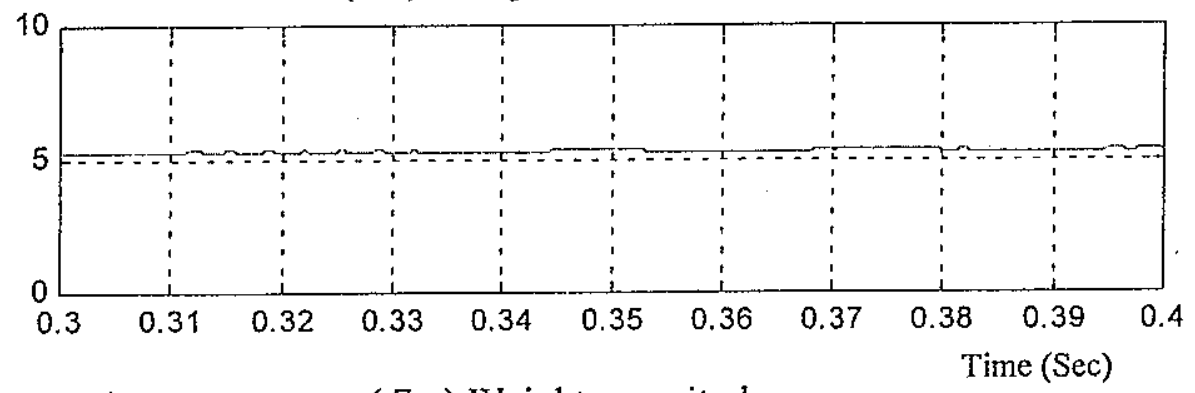

(7-c) Weight magnitude

Fig.(7) Simulation results of proposed SAF using ANN 


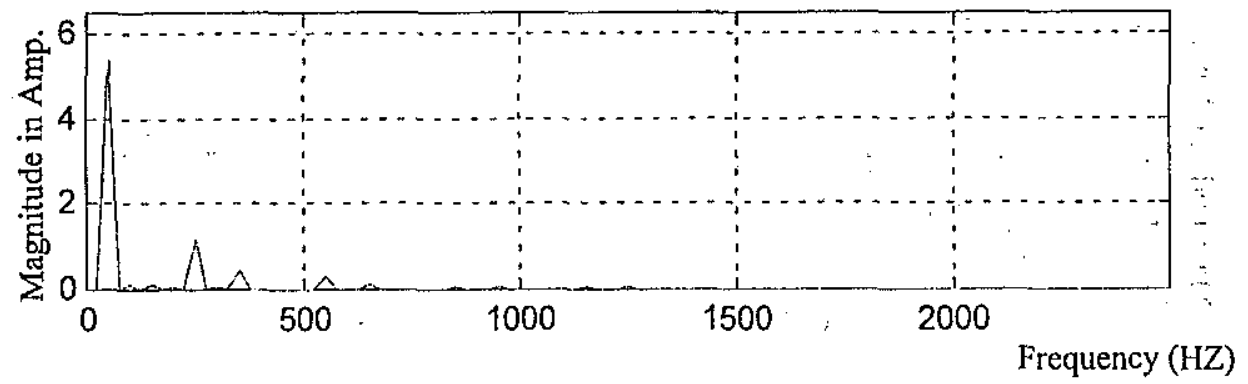

(8-a) Source current spectrum without SAF

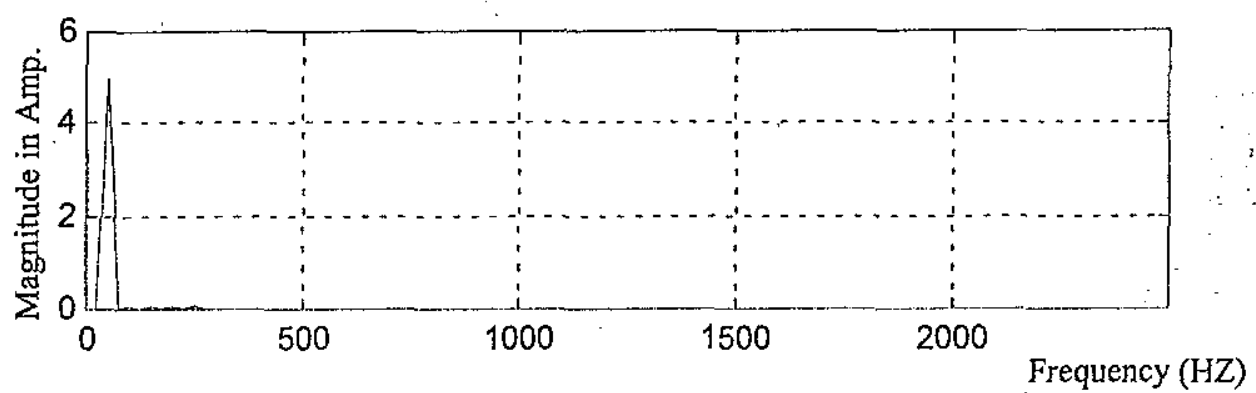

(8-b) Source current spectrum with SAF using PI controller

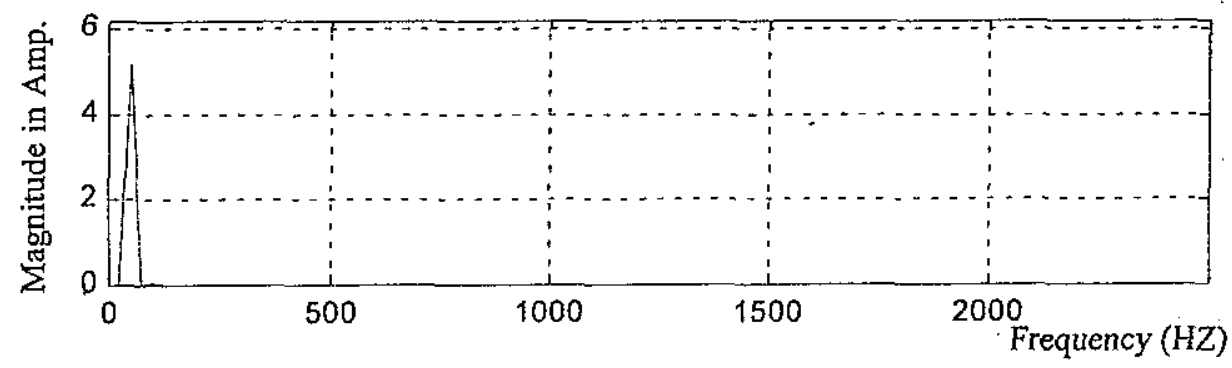

(8-c) Source current spectrum with SAF using ANN

Fig.(8) Frequency spectrum analysis

\section{4-1-2- Step change in load}

To observe the regulating process in two control methods, the simulation has been studied under the step change of the nonlinear load current. In case PI controller Fig. (9) shows, the source current without SAF fig.(9-a), the source current with SAF and the supply voltage fig.(9-b), the DC capacitor voltage fig(9-c). Once the time interval of transient is finished the DC capacitor can be recovered to be reference value, and vice versa. in case PI control. In case of ANN control method, fig. $(10-a, b)$ gives the simulation results of supply current, and weight of ANN. The simulation results show the supply current and voltage are in phase during the load step change. The capacitor voltage will recover to its reference vale after the transient period. The weight magnitude will return to its value as the step change period finished. 


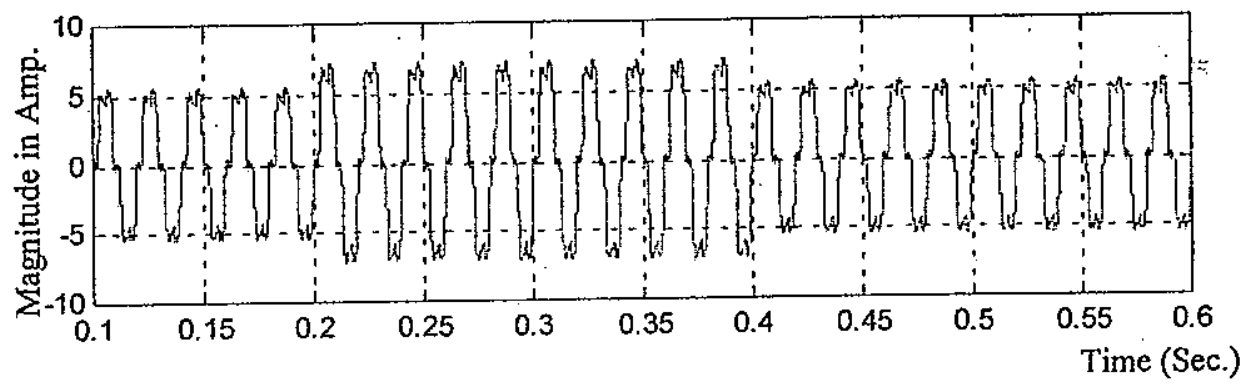

(9-a) Source current without filter

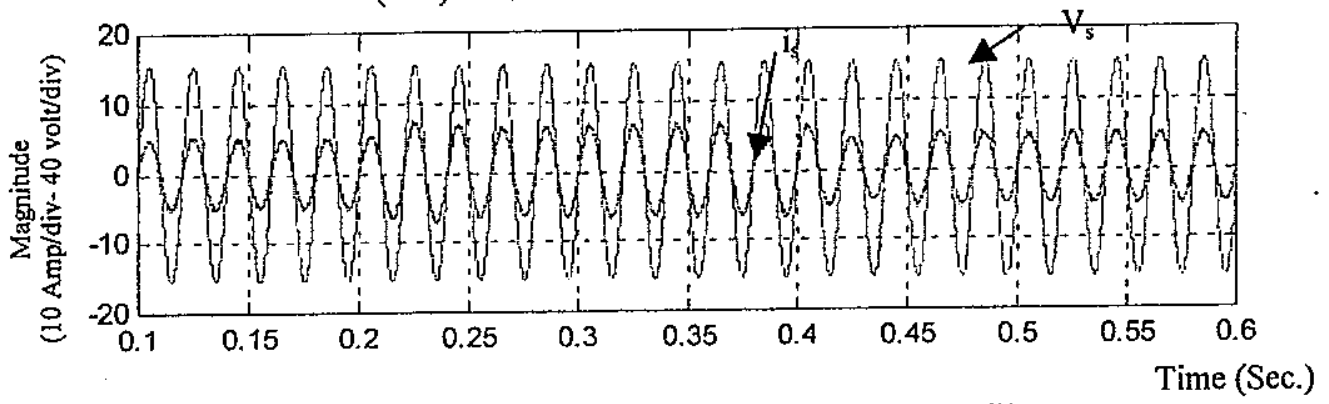

(9-b) Source current and source voltage with filter

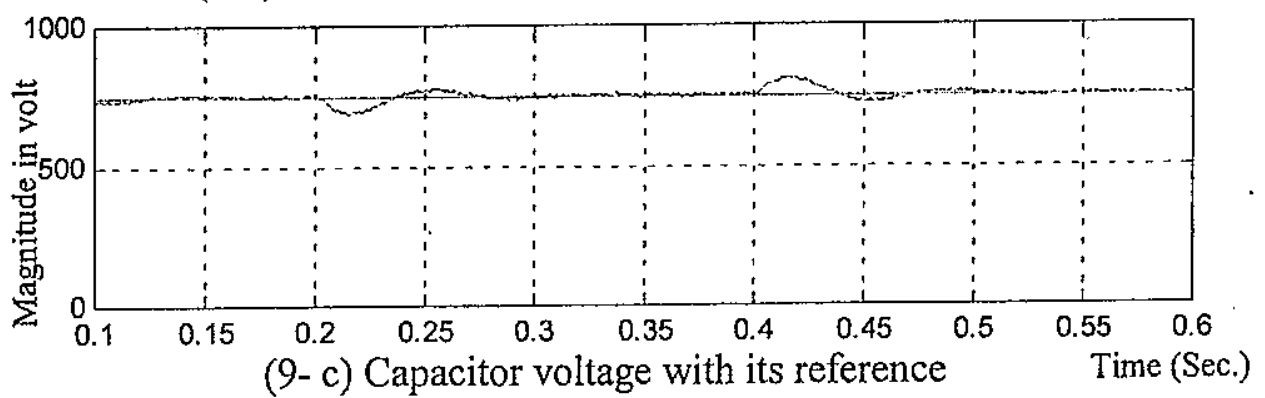

Fig. (9) Simulation results for a step change in load using PI controller.

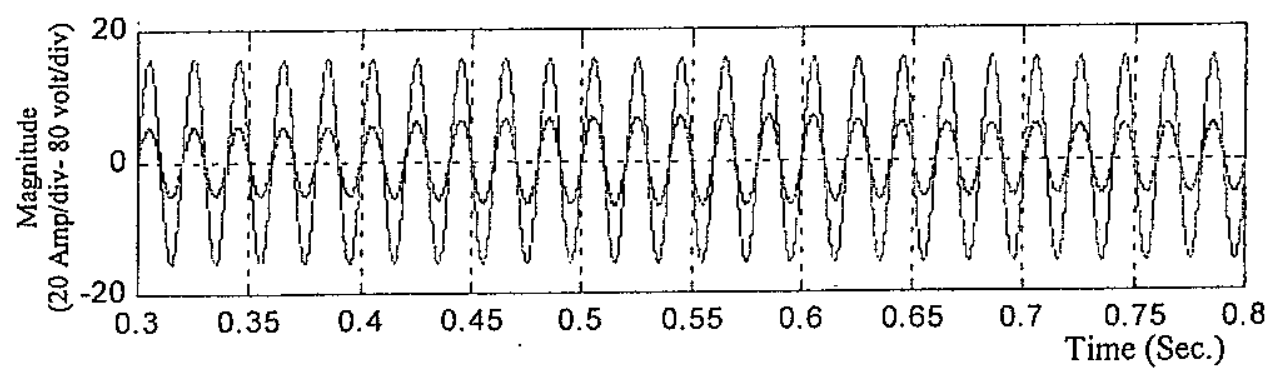

$(10-a)$ Source current and source voltage

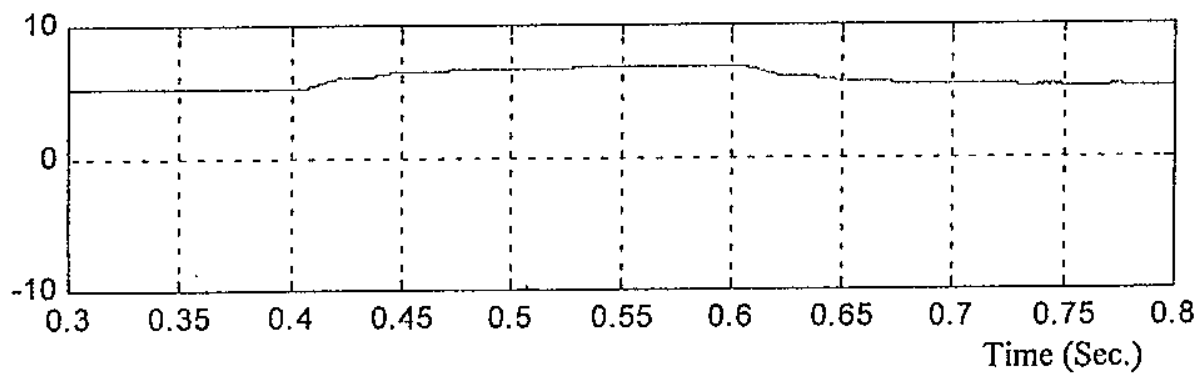

(10-b) Weight magnitude

Fig. (10) Simulation results for a step change in load using ANN. 
4-2- Simulation with firing angle $\alpha=40^{\circ}$ :

The simulation results in case of steady state operation with static load when $\alpha=40^{\circ}$ are presented. Figure (11), shows the simulation waveforms in case of PI control method; the source current without SAF fig.(11-a)', the source current with SAF and the supply voltage fig. (11-b), the SAF current fig. (11-c). InANN control method fig. (12-a,b) shows the waveforms of supply current and voltage besides the compensator current It is noticed that SAF gives a noticeable improvement in the supply current waveform in two control case. In order evaluate the performance of the control methods, total harmonic distortion (THD) calculated for the current before and after compensating. The calculation shows that THD improved as shown in Table (1). The THD in ANN control method is less than THD in case of PI control method as shown in Fig. (16-a,b,c).

\begin{tabular}{|l|l|l|l|}
\hline & Without SAF & $\begin{array}{l}\text { With SAF (PI } \\
\text { controller) }\end{array}$ & With SAF (ANN) \\
\hline$\alpha=0^{\circ}$ & THD $\%=24.04$ & THD $\%=4.6156$ & THD $\%=2.9156$ \\
\hline$\alpha=40^{\circ}$ & $\begin{array}{l}\text { THD } \%= \\
25.1115\end{array}$ & THD $\%=5.58$ & THD $\%=2.9407$ \\
\hline
\end{tabular}

Table l

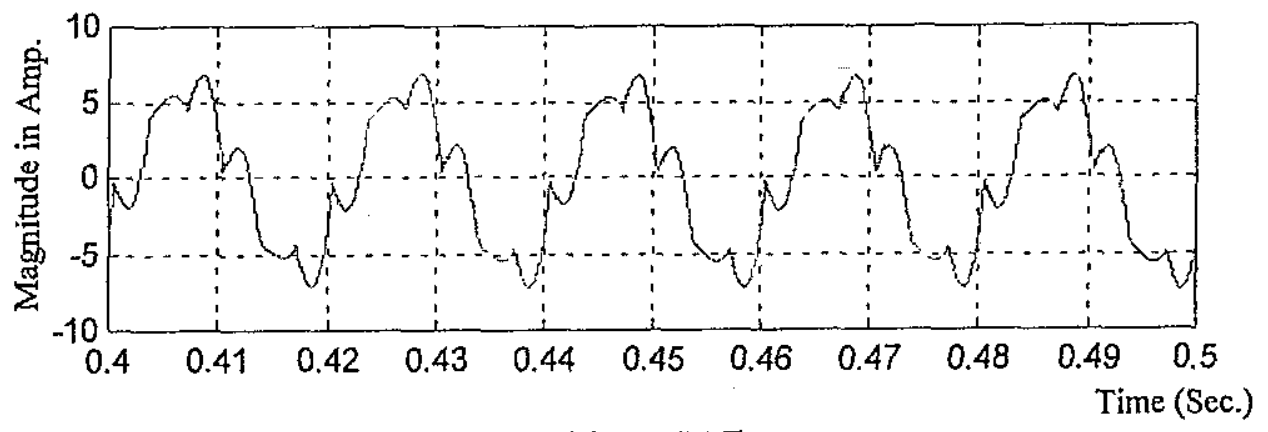

(11-a) Source current without SAF

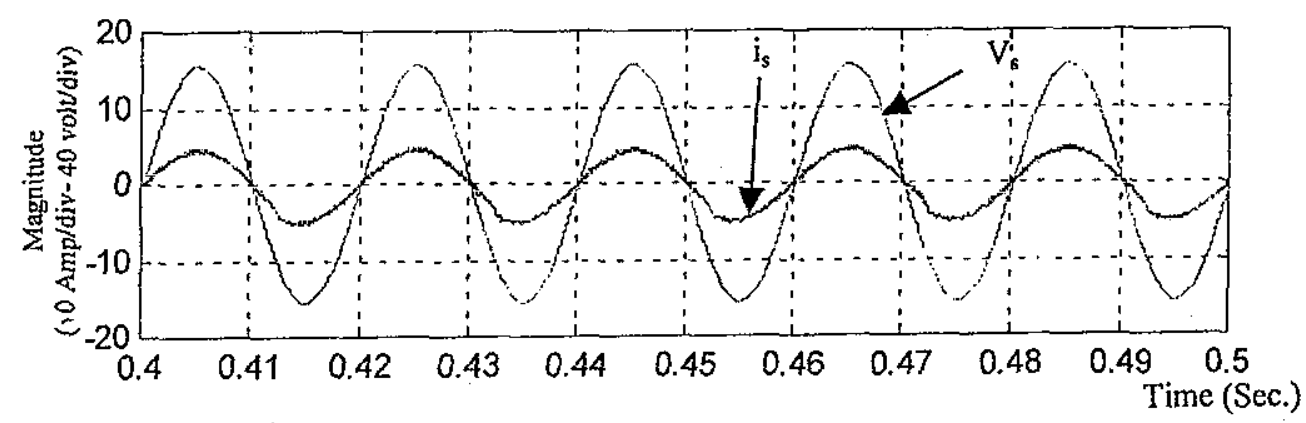

(11-b) Source current and source voltage with filter 


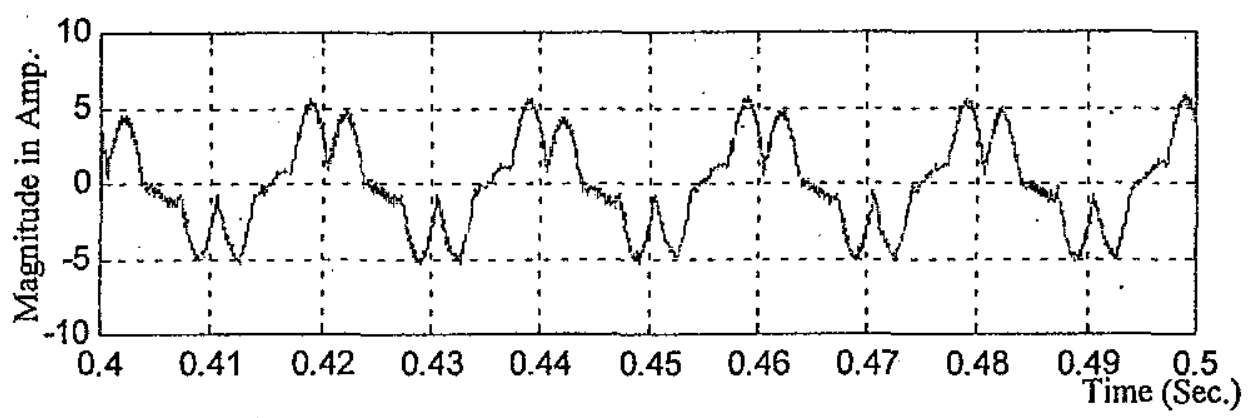

(11- c) Compensating current

Fig.(11) The simulation results of proposed SAF using PI controller

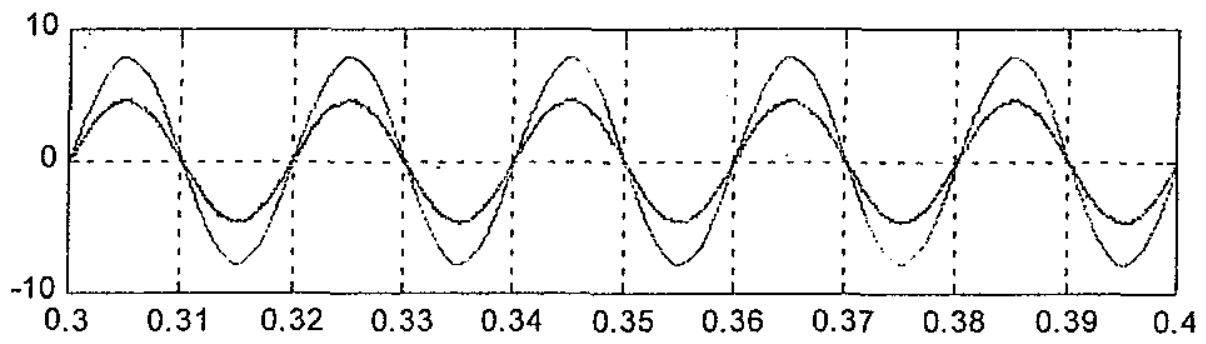

(12-a) Source current and source voltage

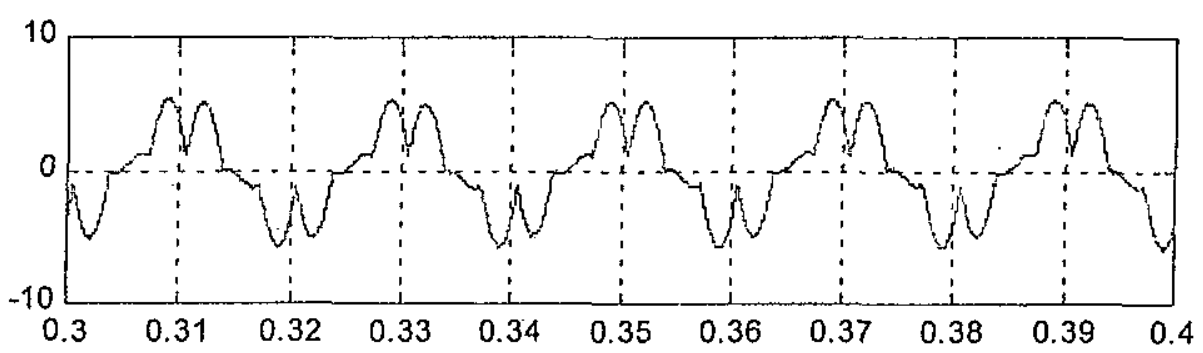

(12-b) Compensating current

Fig.(12) The simulation results of proposed SAF using ANN

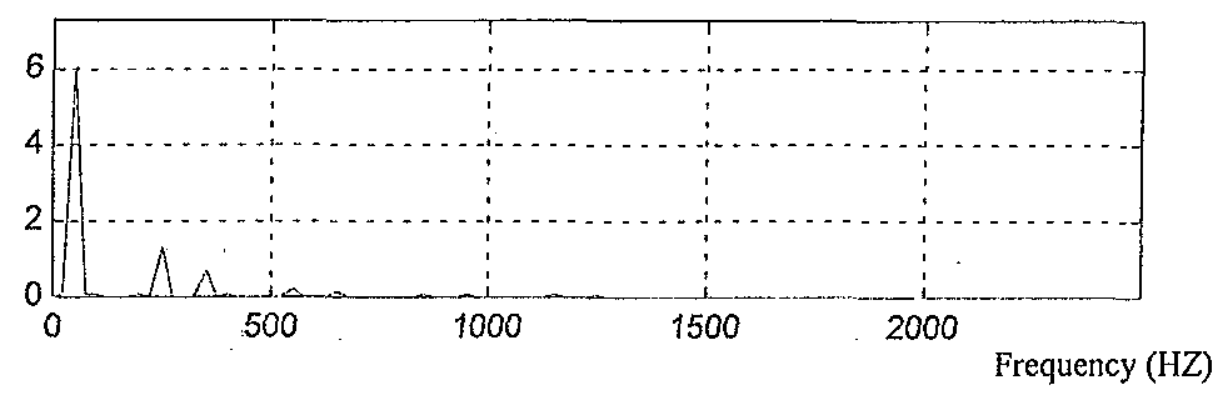

(13-a) Source current spectrum without SAF 


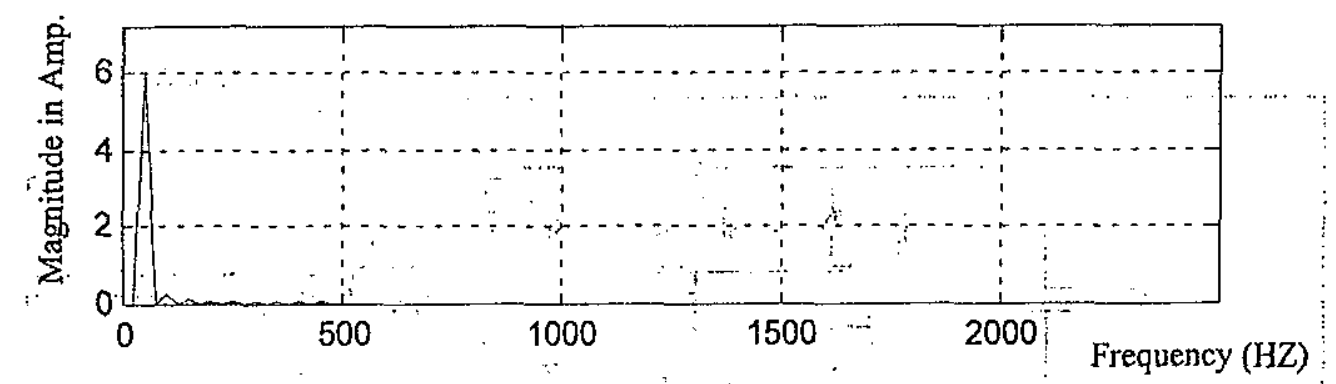

(13-b) Source current spectrum with SAF using PI controller

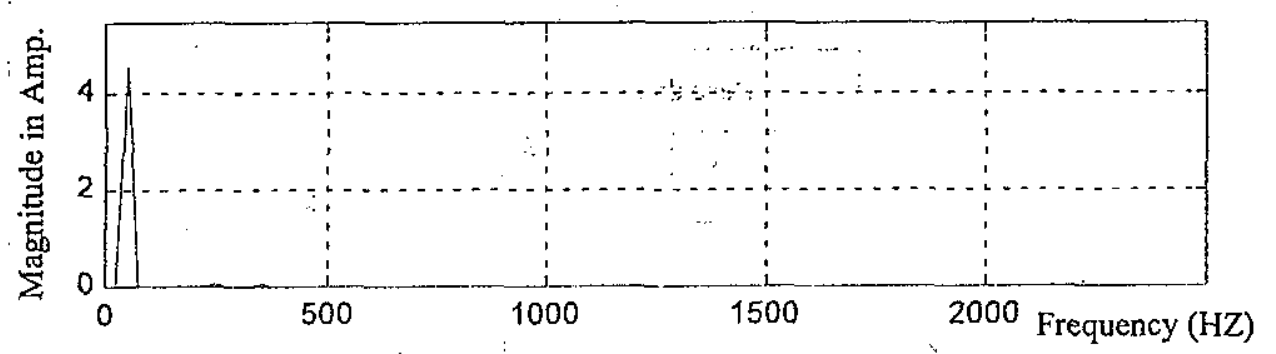

(13-c). Source current spectrum with SAF using ANN

Fig.(13) Frequency spectrum analysis

\section{5- Experimental results:}

Active power filter prototype for experimental purpose has been set up and tested. The power circuit is constructed using Isolated Gate Bipolar Transistors (IGBT's). The voltage sensors are sense the supply voltages and DC capacitor voltage. Also, the current sensors using LEM hall-effect are sense the compensating and supply actual currents. The control scheme is implemented in real time using a 32-bit digital signal processor (DSP-TMS320C31), as shown in Fig.(14). The control algorithm generates three-phase reference supply currents, and compared with the actual currents, the errors are fed to hysteresis current controller. The resulting pulses are gating the IGBT's of VSI which control the SAF.

Figure (15) shows experimental waveforms for the load condition of uncontrolled rectifier. The power factor is improved to unity. Figure (15-a) shows the source current with its voltage in three phase without proposed SAF. Figure (15b) shows the supply phase voltage and supply current. It is clear from Fig. (15-b) that the supply current is nearly sine waveform and follows the reference source current and, also, in phase with supply voltage in its waveform. Figure (15-c) shows the compensating current. From these figures, it is clear that the effectiveness of the proposed controller for active power filter.

\section{6- Conclusion:}

A new control strategy for high performance three phase shunt active filter with unity input power factor has been proposed. Two control strategy are considered, the first is PI-controller and the second is ANN. The control scheme using three 


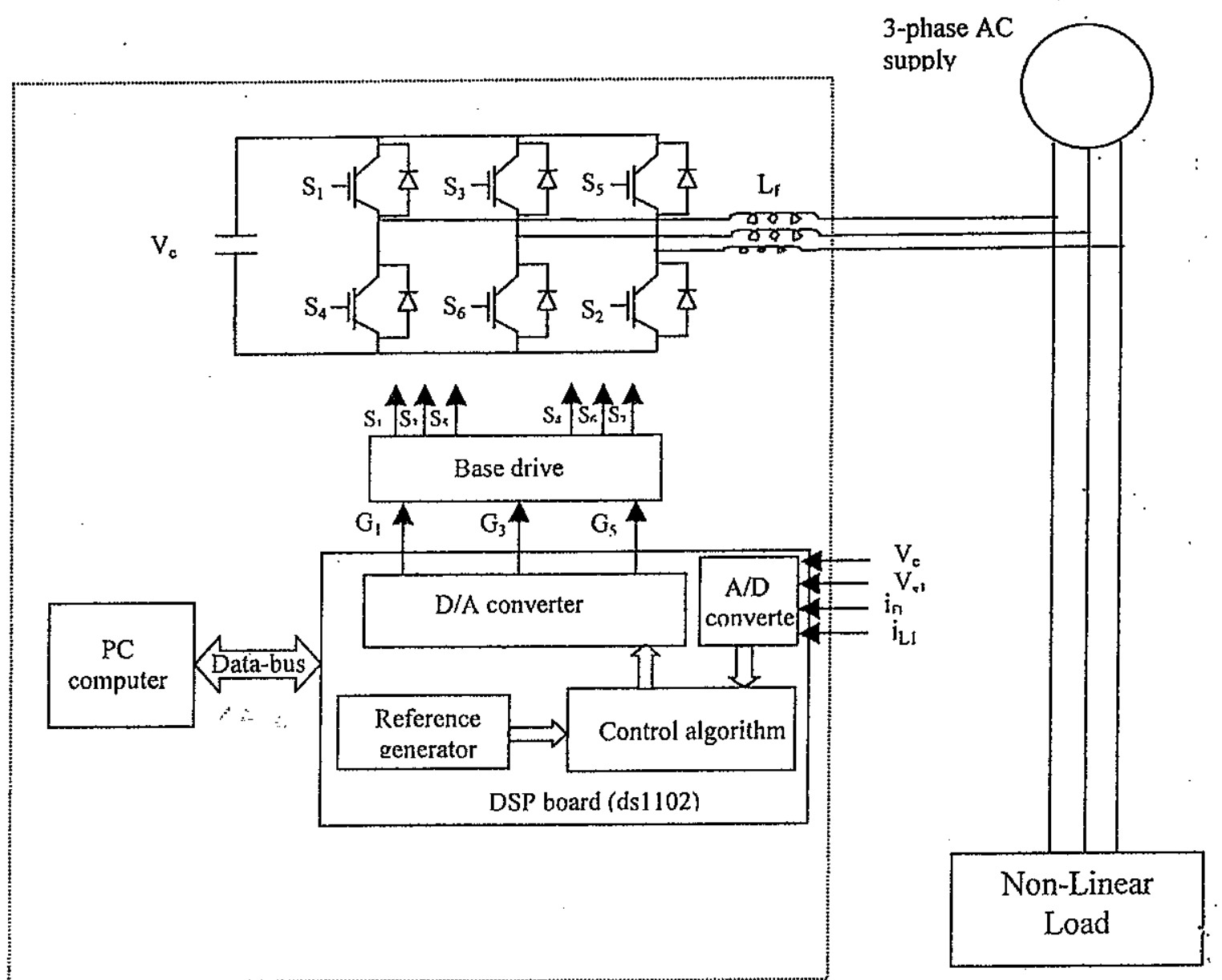

Fig.(14) Digital Signal Processing (DSP) system hardware
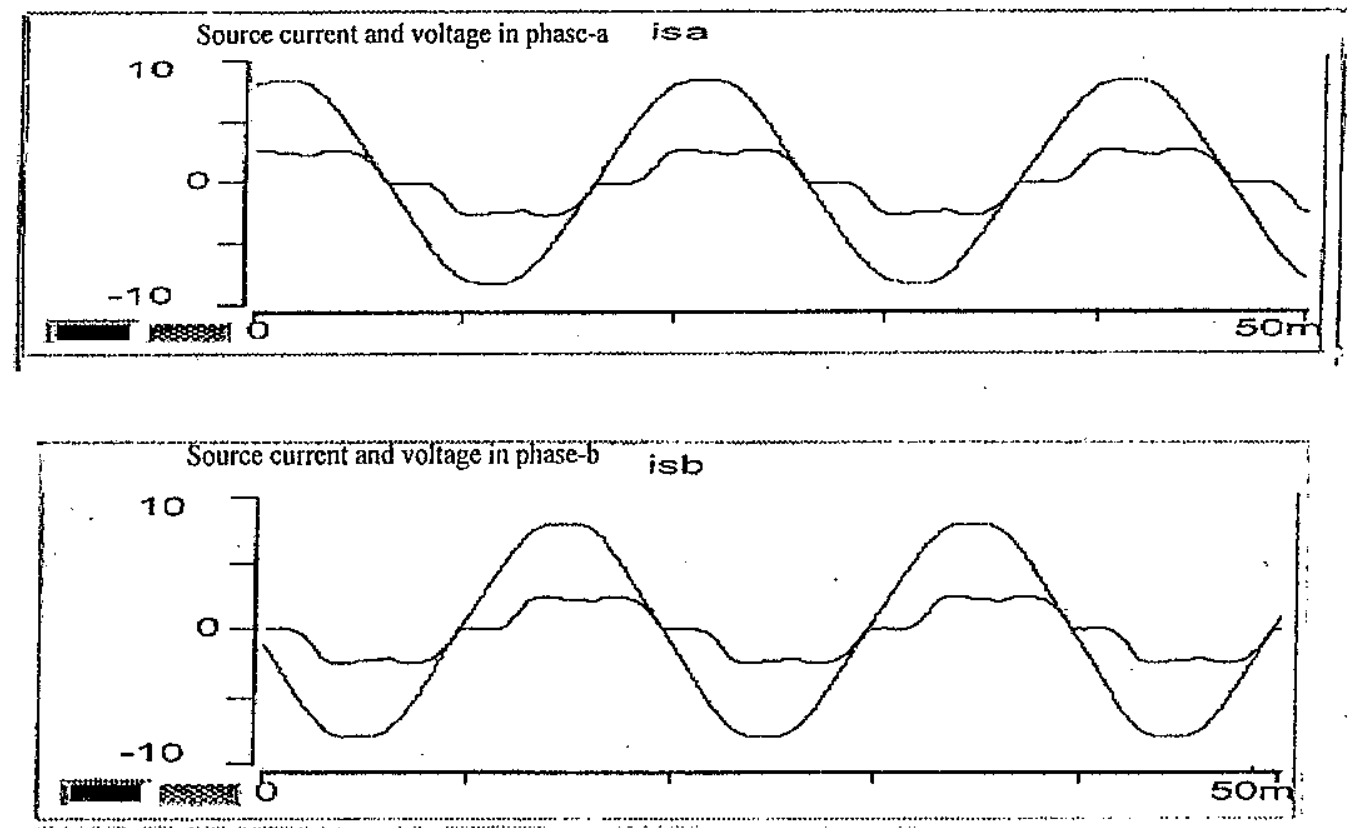


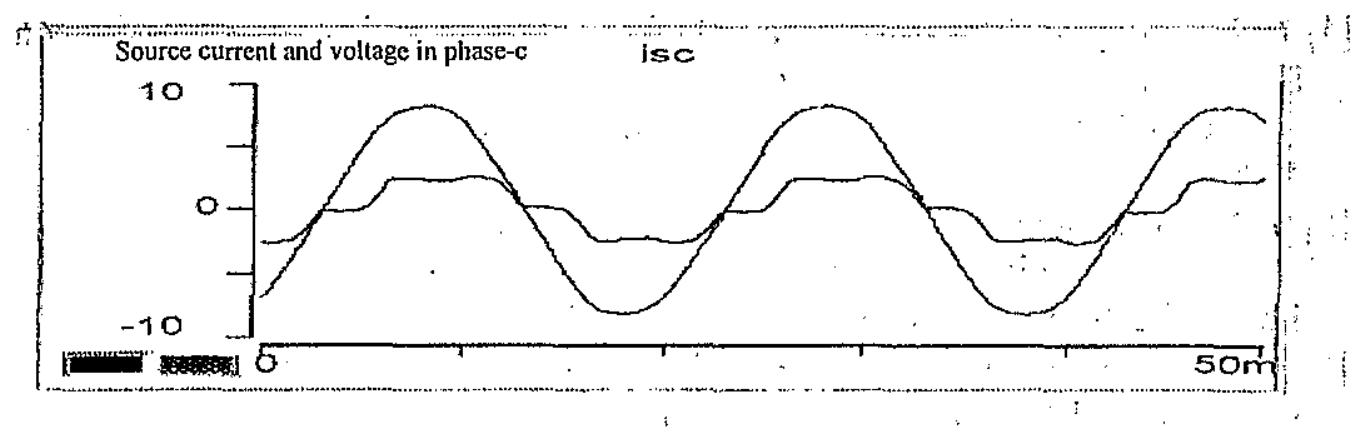

(15-a) source currents and voltage without SAF

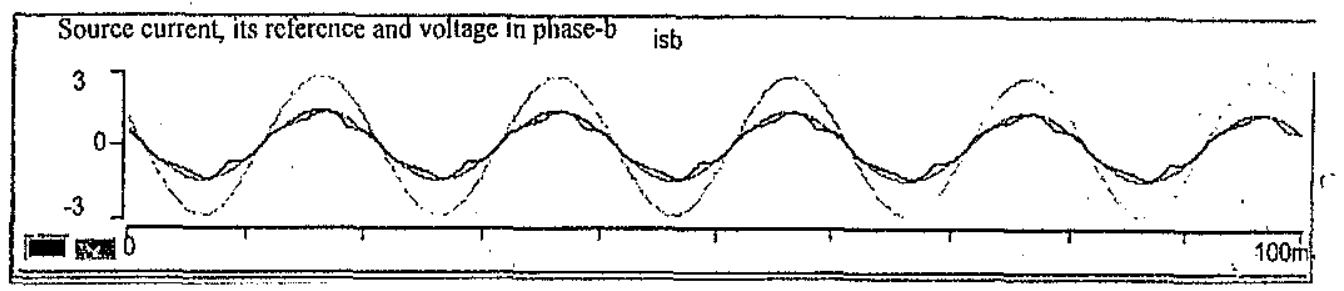

(15-b) Source current and voltage with SAF

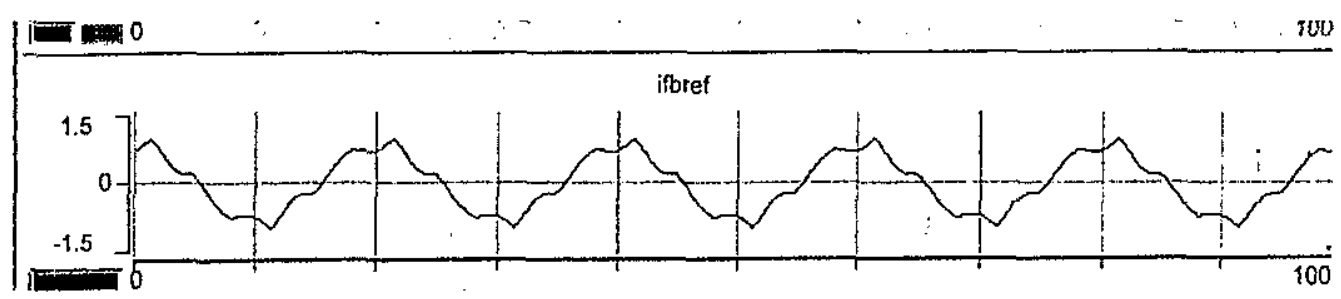

\section{(15-c) Compensation current}

Fig.(15) Experimental results of proposed SAF

independent hysteresis current controller has been implemented. The operation and modeling of the SAF have been described and analysised.

An experimental SAF has been carried out on DSP to explore the advantages and practical implementation with the proposed control strategy: The experimental and simulation results shows that the proposed system has a good performance in the harmonic compensation and improve the input power factor.

\section{8- References:}

[1] J. W. Dixon, G. Venegas, and L. A. Moran, "A Series Power Filter Based on a Sinusoidal Current-Controlled Voltage-Source Inverter" IEEE Transactions on. Industrial Electronics, Vol. 44, No. 5, October 1997.

[2] S. G. Jeong, and M. H. Woo, "DSP-Based Active Power Filter with Predictive Current Control" IEEE Tranactions on Industrial Electronics, Vol. 44, No. 3, June 1997.

[3] S. Buso, L. Malesoni, and P. Mattavelli, "Comparison of Current Control Techniques for Active Filter Applications" IEEE Transactions on Industrial Electronics, Vol. 45, No. 5, October 1998. 
[4] P. T. Cheng, S. Bhattacharya, and D. D. Divan, "Line Harmonics Reduction in High-Power Systems Using Square-Wave Inverters-Based Dominant Harmonic" Active Filter" IEEE Transactions on Power Electronics, Vol. 14, No. 2, March 1999.

[5] S. J. Huang, and J. C. Wu, "A Control Algorithm for Three-Phase Three-Wired Active Power Filters Under Nonideal Mains Voltages" IEEE Transactions on Power Electronics, Vol. 14, No. 4, July 1999.

[6] P. Verdelho, and G. D. Marques, "Four-Wire Current-Regulated PWM Voltage Converter" IEEE, Transactions on Industrial Electronics, Vol. 45. No. 5. October 1998.

[7] F. Kamran, and T. G. Habetler, "Combined Deatbeat Control of a Series-Parallel Converter Combination Used as a Universal Power Filter" IEEE Transactions on Power Electronics, Vol. 13, No. 1, January 1998.

[8] A. Dastfan, V. J. Gosbell, and D. Platt, "Control of a New Active Power Filter Using 3-D Vector Control" IEEE Transactions on Power Electronics, Vol. 14, No. 4, July 1999.

[9] P. Verdelho, and G. D. Marques, "Four-Wire Current-Regulated PWM Voltage Converter" IEEE, Transactions on Industrial Electronics, Vol. 15. No. 1, January 2000 .

[10] A. Chandra, B. Singh, and K. Al-Haddad, "An Improved Control Algorithm of Shunt Active Filter for Voltage Regulation, Harmonic Elimination, Power-Factor Correction, and Balancing of Nonlinear Loads" IEEE Transaction on Power Electronics, Vol. 15. No. 6, May 2000.

[11] M. Salo, and H. Tussa, "A Vector Controlled Current-Source PWM Rectifier With a Novel Current Damping Method" IEEE Transactions on Power Electronics, Vol. 15, No. 6, May2000.

[12] S. Buso, L. Malesani, P. Mattavelli, and R. Veronese, "Design and Fully Digital Control of Parallel Active Filters for Thyristor Rectifiers to Comply with IEC-1000-3-2 Standards" IEEE Transactions on Industry Applications, Vol. 34, No. 3, May/June 1998.

[13] H. Fujita, and H. Akagi, "The Unified Power Quality Conditioner: The Integration of Series-and Shunt-Active Filters" IEEE, Transactions on Power Electronics, Vol. 13, No. 2, March 1998.

[14] P. G. Barbosa, J. A. Santisteban, and E. H. Watanabe, "Shunt-Series Active Power Filter for Rectifiers AC and DC Sides" IEE Proc.-Electr. Power Appl., Vol. 145, No. 6, November 1998. 
مرشح قدرة فعال ثلاثي الاوجة يعثمل على شبكة الذكاء ألاصطناعى للتحكم فى التيار بواسطة مغيرمصدر الجهاجد

\author{
م/ مداى محمد محروس \\ الصنانع الدولية لدرفلة الصلب المروت
}

داعلوى الحولى

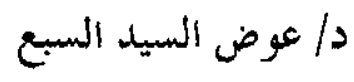

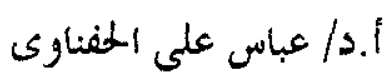

كلية الهندسة بشبين الكوم على المغنام

نظرا للتطور السريع لانستخلامات إلكترونات القوى في نظم القوى الكهربية ، وجد أن الأمال المحكومة

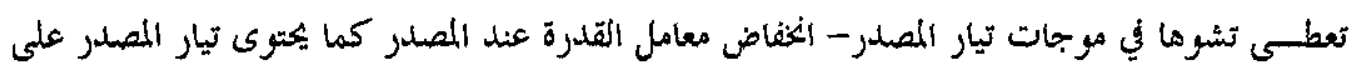

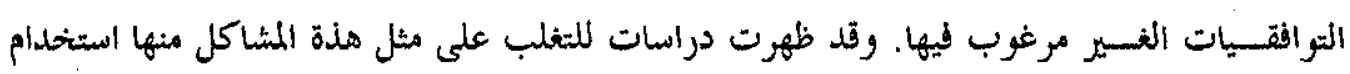

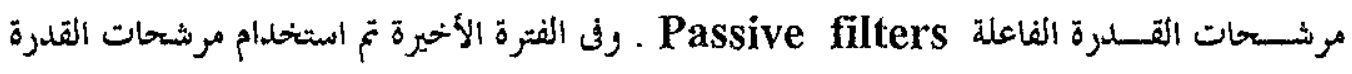

$$
\text { الفعالة Active filters }
$$

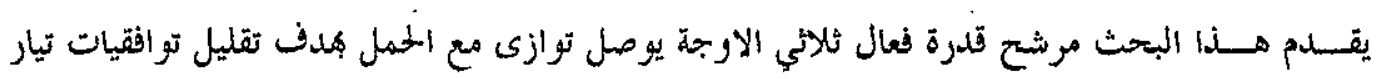

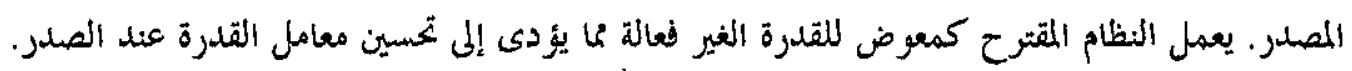

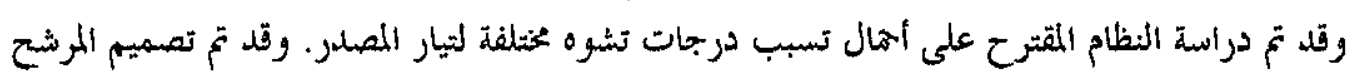

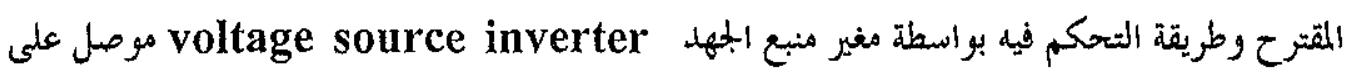

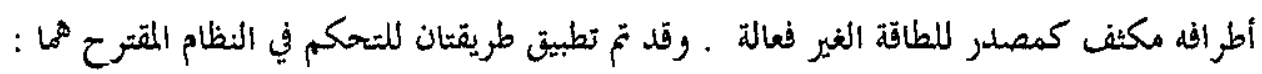
1- طريقة تحكم تفاضلي - مكاملي

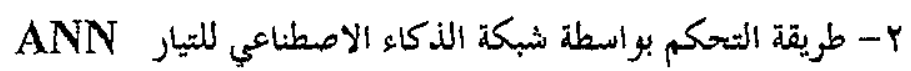

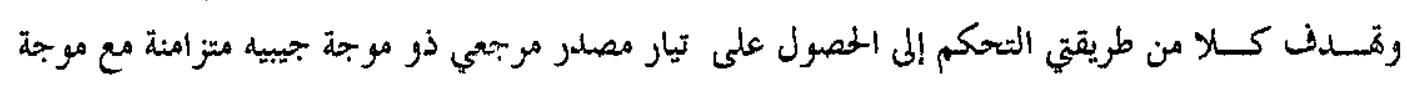

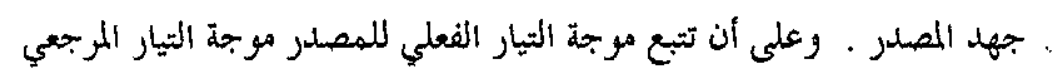

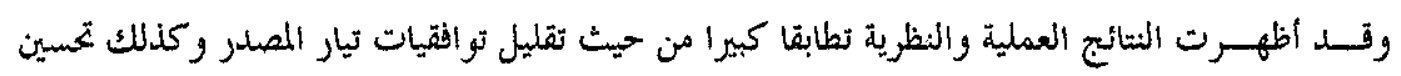

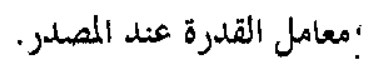

